\title{
Spatial occurrence of dengue fever and its relationship with land use in Selangor, Malaysia
}

\author{
Haidar Rizal Toha ${ }^{1 *}$, Jamal Hisham Hashim ${ }^{1,2}$, Mazrura Sahani ${ }^{1}$, Mohd Shahir Shamsir ${ }^{3}$ \\ From 7th Postgraduate Forum on Health Systems and Policies \\ Phitsanulok, Thailand. 24-25 June 2013
}

\section{Background}

Dengue fever has a profound impact in Malaysia, and globally, it has a strong potential to spread to new territories as a consequence of human activities and climate change that modify the environment. Environmental factors can affect the disease epidemic via their influence on vector's habitat and propagation. Among the economic costs borne in dealing with this matter related to epidemic identification and vector surveillance. The relationship between dengue fever and environmental factors namely land use and degree of urbanisation were investigated in the state of Selangor, Malaysia.

\section{Materials and methods}

Spatial analysis of serologically confirmed dengue cases using Global Moran I and Average Nearest Neighbour methods in four districts, namely Hulu Selangor, Klang, Petaling and Sepang was done to show clustering of cases.

\section{Conclusions}

The result of this study is useful for application as a tool to guide health authorities in dengue fever prevention and control activities.

\section{Authors' details}

'Jabatan Kesihatan Masyarakat, Pusat Perubatan Universiti Kebangsaan Malaysia, Jalan Yaacob Latif, Bandar Tun Razak, 56000 Cheras, Kuala Lumpur, Malaysia. ' United Nations University-International Institute for Global Health, UKMMC Complex, Jalan Yaacob Latiff, Bandar Tun Razak, 56000 Cheras, Kuala Lumpur, Malaysia. ${ }^{3}$ Faculty of Bioscience and Bioengineering, Universiti Teknologi Malaysia, Skudai, Johor, Malaysia.

Published: 29 January 2014

doi:10.1186/1471-2458-14-S1-P16

Cite this article as: Toha et al:: Spatial occurrence of dengue fever and its relationship with land use in Selangor, Malaysia. BMC Public Health 2014 14(Suppl 1):P16.

\section{Results}

The clusterings of cases were statistically significant at differing range of distances. Formation of maps of case location, epidemic location, high risk areas and areas that are affected by nearby land uses were done. The land use maps were for agriculture, stagnant water bodies, housing, industry, open land and drainage in all the four districts and the affected areas were shown as hotspots of dengue cases.

\footnotetext{
* Correspondence: hrt-warhead@hotmail.com

1 Jabatan Kesihatan Masyarakat, Pusat Perubatan Universiti Kebangsaan Malaysia, Jalan Yaacob Latif, Bandar Tun Razak, 56000 Cheras, Kuala Lumpur, Malaysia

Full list of author information is available at the end of the article
}

Submit your next manuscript to BioMed Central and take full advantage of:

- Convenient online submission

- Thorough peer review

- No space constraints or color figure charges

- Immediate publication on acceptance

- Inclusion in PubMed, CAS, Scopus and Google Scholar

- Research which is freely available for redistribution 